\title{
Trend Analyses of Critical Values Obtained for Range CBR Distance Achievable in Ubicomp MANETs Using Location- Aware Transmission Strategies.
}

\author{
M. Kaleem GALAMALI, Assoc. Prof Nawaz MOHAMUDALLY
}

\begin{abstract}
Many fields of research are concerned with pervasive computing, e.g., location-tracking, ubicomp functionalities and MANET transmission strategies. In spite of all intense research put in these sub-fields [1-60], their merging still lies along a long way ahead before yielding useful results. More distinctly here, the exertion of location-aware transmission strategies is envisioned to enhance energy management in ubicomp. Such enhancements expected [1] encompass improvements in location accuracy and refresh rates, the application of land-based GPS systems, development of better protocols optimised for transmission according to distance criteria and fine-tuning the precision of the distance criteria to apply the protocol. The know-how of distance coverages by transmitted packets in ubicomp environments and corresponding variations over different node densities, is assuredly profitable for refining transmission protocols in MANETs. One particular empirical study was carried out formerly [29] in which the metric Range CBR Distance, R_CBR_Dis, was exposed. This was further substantiated by a successive study [45] in which trends of parameters of equations for metric R_CBR_Dist were analysed.
\end{abstract}

In this paper, the successive investigation of good importance is laid as: "What are the observable critical values in R_CBR_Dist trends? What are the trends of variation observable within each critical value for metric R_CBR_Dist over varying node densities?" Designers will use these results in order to produce more sophisticated and "realistic" ubicomp schemes for future ubicomp tools.

This study remains a follow-up of previous studies [1-60].

Key terms: Ubicomp- Ubiquitous Computing, MAUCMobile and Ubiquitous Computing, R_CBR_Dist- Range CBR Distance, CBR- Constant Bit Rate, MANET- Mobile Adhoc Network, CV- Critical Value.

M. Kaleem GALAMALI,

University of Technology Mauritius (student) Mauritius

Assoc. Prof Nawaz Mohamudally University of Technology Mauritius, Mauritius

\section{Introduction}

It is anticipated that for quite long in the future, quite a lot of ubicomp environments will be sub-standardly equipped with network resources on top of which other heterogeneities may be adding complexities. Among these heterogeneities, there can be differences in accuracy level of distance measurement, location refresh rates and performance characteristics of existing protocols. Environments with substandard solution support, will welcome MANETs as the applicable solution. The performance features of MANETs, more strictly energy consumption features, may be intensified with location-aware transmission. Metrics analyses in ubicomp remain a method of compelling importance for studying distance coverage attributes. One such linked metric was produced in a previous paper [29] in which metric R_CBR_Dist was expounded as following the normal distribution model:

$F(x)=b *(1 /(a * \operatorname{sqrt}(2 * p i))) * \exp \left(-(x-c)^{2} / 2 * a^{2}\right)$

The associated follow-up study [45] was undertaken to mathematically model the three parameters of equation observed above. Results will be contributory towards more befitting understanding of the evolution and predictability of ubicomp environments. There are slowly developing progresses in this direction which will empower designers to produce better realistic scenarios for simulations, based on which more beneficial test cases can be prepared and ran over experimental components for middleware and communication protocols.

The analysis hence yearned for metric R_CBR_Dist is the identification of observable critical values obtained during experiments execution and formulation of relative theoretical tendencies of such CVs over varying node densities. Eight such CVs were observed.

The key contribution of this paper is the founding of the trends of variations for each of the eight CVs observed for metric R_CBR_Dist illustrated previously [29, 45] over node numbers ranging from 7 until 56. Such extension of information must necessarily be rendered available in a conducive format to more fruitfully assist designers in understanding the evolution and predictability of ubicomp behaviour and be favourably equipped to carry out reliable simulation scenarios testing of newly designed communication components. The rest of this paper is organised as follows: section 2- R_CBR_Dist Critical Values, section 3- Critical Values Trend Analyses- Metric R_CBR_Dist, section 4-Conclusion and References. 
Proc. of The Seventh Intl. Conf. On Advances In Computing, Control And Networking - ACCN 2017 Copyright $(\subseteq$ Institute of Research Engineers and Doctors, USA .All rights reserved.

ISBN: 978-1-63248-134-4 doi: 10.15224/ 978-1-63248-134-4-08

\section{R_CBR_Dist Critical Values.}

2.0 Critical Values Identified.

Eight CVs were identified as follows: Column headings are: $\quad$ C1 $\rightarrow$ R_CBR_Dist $\quad \mathrm{CV}, \quad \mathrm{C} 2 \rightarrow$ Meaning of R_CBR_Dist CV, C3 $\rightarrow$ Corresponding figure number for R_CBR_Dist CV.

\begin{tabular}{|l|l|c|}
\hline C1 & C2 & C3 \\
1 & Smallest range distance noted. & 1 \\
\hline 2 & $\%$ CBR at smallest range distance. & 2 \\
\hline 3 & Largest range distance noted. & 3 \\
\hline 4 & $\%$ CBR at largest range distance. & 4 \\
\hline 5 & $\%$ CBR at peak value of range distance. & 5 \\
\hline 6 & $\%$ CBR with range < modal range value. & 6 \\
\hline 7 & $\%$ CBR with range > modal range value. & 7 \\
\hline 8 & $95 \%$ CBR with max range as from & 8 \\
\hline
\end{tabular}

Table 1: R_CBR_Dist Critical Values

\subsection{Experimental Critical Values Obtained.}

Values obtained during experiments are summarised below. Values have been rounded to a maximum of 9 decimal places. Column heading NN $\rightarrow$ Node Number.

\begin{tabular}{|c|c|c|c|c|c|}
\hline NN & CV1 & CV2 & CV3 & CV4 & CV5 \\
\hline 7 & 0 & 0.555555556 & 359 & 0.079365079 & 1.555555556 \\
\hline 8 & 0 & 0.557147405 & 359 & 0.079592486 & 1.560012735 \\
\hline 9 & 0 & 0.555555556 & 359 & 0.079365079 & 1.428571429 \\
\hline 10 & 1 & 0.238095238 & 363 & 0.238095238 & 1.507936508 \\
\hline 11 & 1 & 0.238095238 & 363 & 0.317460317 & 1.380952381 \\
\hline 12 & 1 & 0.238473768 & 363 & 0.317965024 & 1.589825119 \\
\hline 13 & 1 & 0.158730159 & 363 & 0.238095238 & 1.507936508 \\
\hline 14 & 1 & 0.158730159 & 363 & 0.317460317 & 1.507936508 \\
\hline 15 & 1 & 0.158730159 & 363 & 0.317460317 & 1.666666667 \\
\hline 16 & 1 & 0.158730159 & 363 & 0.317460317 & 1.380952381 \\
\hline 17 & 1 & 0.079365079 & 363 & 0.317460317 & 1.349 \\
\hline 18 & 1 & 0.079365079 & 363 & 0.317460317 & 1.587301587 \\
\hline 19 & 1 & 0.079365079 & 363 & 0.317460317 & 1.507936508 \\
\hline 20 & 1 & 0.079365079 & 363 & 0.317460317 & 1.349206349 \\
\hline 21 & 1 & 0.079365079 & 369 & 0.079365079 & 1.428571429 \\
\hline 22 & 1 & 0.079365079 & 369 & 0.079365079 & 1.428571429 \\
\hline 23 & 1 & 0.079365079 & 389 & 0.238 & 1.714 \\
\hline 24 & 1 & 0.079365079 & 389 & 0.238095238 & 1.349206349 \\
\hline 25 & 1 & 0.079365079 & 389 & 0.238095238 & 1.349206349 \\
\hline 26 & 1 & 0.079365079 & 381 & 0.238095238 & 1.666666667 \\
\hline 27 & 1 & 0.079365079 & 381 & 0.238095238 & 1.507936508 \\
\hline 28 & 1 & 0.079365079 & 388 & 0.158730159 & 1.507936508 \\
\hline 29 & 1 & 0.079365079 & 388 & 0.158730159 & 1.507936508 \\
\hline 30 & 1 & 0.079365079 & 389 & 0.079365079 & 1.507936508 \\
\hline 31 & 1 & 0.079365079 & 389 & 0.238095238 & 1.587301587 \\
\hline 32 & 1 & 0.079365079 & 389 & 0.238095238 & 1.428571429 \\
\hline 33 & 1 & 0.079365079 & 389 & 0.238095238 & 1.507936508 \\
\hline 34 & 1 & 0.079365079 & 389 & 0.238095238 & 1.428571429 \\
\hline 35 & 1 & 0.079365079 & 389 & 0.079365079 & 1.460317460 \\
\hline 36 & 1 & 0.079365079 & 389 & 0.079365079 & 1.349206349 \\
\hline 37 & 1 & 0.079377679 & 389 & 0.238133037 & 1.508175901 \\
\hline 38 & 1 & 0.079365079 & 389 & 0.238095238 & 1.587301587 \\
\hline 39 & 1 & 0.079365079 & 389 & 0.238095238 & 1.507936508 \\
\hline 40 & 1 & 0.079365079 & 389 & 0.238095238 & 1.587301587 \\
\hline 41 & 1 & 0.079365079 & 389 & 0.238095238 & 1.666666667 \\
\hline 42 & 1 & 0.079365079 & 389 & 0.238095238 & 1.587301587 \\
\hline 43 & 1 & 0.079365079 & 389 & 0.238095238 & 1.507936508 \\
\hline 44 & 1 & 0.079415502 & 389 & 0.238246506 & 2.303049555 \\
\hline 45 & 1 & 0.079365079 & 389 & 0.238095238 & 1.507936508 \\
\hline 46 & 1 & 0.079365079 & 389 & 0.238095238 & 1.746031746 \\
\hline 47 & 1 & 0.079365079 & 389 & 0.238095238 & 1.428571429 \\
\hline 48 & 1 & 0.079365079 & 389 & 0.238095238 & 1.507936508 \\
\hline
\end{tabular}

\begin{tabular}{|l|l|l|l|l|l|}
\hline 49 & 1 & 0.079365079 & 389 & 0.238095238 & 1.428571429 \\
\hline 50 & 1 & 0.079365079 & 368 & 0.158730159 & 1.666666667 \\
\hline 51 & 1 & 0.079365079 & 368 & 0.158730159 & 1.428571429 \\
\hline 52 & 1 & 0.079365079 & 368 & 0.158730159 & 1.507936508 \\
\hline 53 & 1 & 0.079365079 & 368 & 0.158730159 & 1.746031746 \\
\hline 54 & 1 & 0.079365079 & 368 & 0.158730159 & 1.587301587 \\
\hline 55 & 1 & 0.079365079 & 368 & 0.158730159 & 1.349206349 \\
\hline 56 & 1 & 0.079365079 & 368 & 0.158730159 & 1.587301587 \\
\hline
\end{tabular}

Table 2(a): Experimental Critical Values Obtained(1)

\begin{tabular}{|c|c|c|c|}
\hline NN & CV6 & CV7 & CV8 \\
\hline 7 & 50.301587302 & 38.619047619 & \\
\hline 8 & 59.710283349 & 38.729703916 & 283 \\
\hline 9 & 39.269841270 & 59.301587302 & \\
\hline 10 & 29.126984127 & & \\
\hline 11 & 44.523809524 & 54.095238095 & \\
\hline 12 & 54.260731320 & 44.149443561 & \\
\hline 13 & 81.031746032 & 17.460317460 & 296 \\
\hline 14 & 43.507936508 & 54.984126984 & \\
\hline 15 & 46.03 & & \\
\hline 16 & 33.9 & & \\
\hline 17 & 46.2 & & 03 \\
\hline 18 & & & \\
\hline 19 & 78.4920634 & 20.00000 & 303 \\
\hline 20 & 43.0 & & \\
\hline 21 & & & \\
\hline 22 & & & \\
\hline 23 & & & 306 \\
\hline 24 & & & \\
\hline 25 & & 32.82 & \\
\hline 26 & & & \\
\hline 27 & & & \\
\hline 28 & & & \\
\hline 29 & 47.38 & & \\
\hline 30 & & & \\
\hline 31 & & & \\
\hline 32 & & & \\
\hline 33 & & & \\
\hline 34 & & & \\
\hline 35 & & & \\
\hline 36 & & & \\
\hline 37 & & & \\
\hline 38 & & & \\
\hline 39 & 33. & 24 & 317 \\
\hline 40 & 33.09 & 65.31746 & 320 \\
\hline 41 & 42.301587302 & 56.03 & \\
\hline 42 & 41.666666667 & 56.746031746 & 322 \\
\hline 43 & & & \\
\hline 44 & & 38.1 & 319 \\
\hline 45 & 59.682539683 & 38.809523810 & 317 \\
\hline 46 & 60.079365079 & 38.174603175 & 318 \\
\hline 47 & 63.809523810 & 34.761904762 & 318 \\
\hline 48 & 79.920634921 & 18.571428571 & 320 \\
\hline 49 & & & 322 \\
\hline 50 & 58.412698413 & 39.920634921 & 323 \\
\hline 51 & 64.523809524 & 34.047619048 & 323 \\
\hline 52 & 48.888888889 & 49.603174603 & 321 \\
\hline 53 & 43.015873016 & 55.238095238 & 323 \\
\hline 54 & 57.777777778 & 40.634920635 & 323 \\
\hline 55 & 36.031746032 & 62.619047619 & 322 \\
\hline 56 & 57.460317460 & 40.952380952 & 321 \\
\hline
\end{tabular}

Table 2(b): Experimental Critical Values Obtained(2)

\section{Critical Values Trend Analyses- Metric R_CBR_Dist.}


Proc. of The Seventh Intl. Conf. On Advances In Computing, Control And Networking - ACCN 2017 Copyright $(\subseteq$ Institute of Research Engineers and Doctors, USA .All rights reserved. ISBN: 978-1-63248-134-4 doi: 10.15224/ 978-1-63248-134-4-08

3.0 General Procedure Adopted.

A four-step procedure has been defined:

i. The tabulated data for each R_CBR_Dist CV is plotted onto gnuplot.

ii. Graphical analyses are performed and general observations noted.

iii. Different equations of fit are attempted. For three $\mathrm{CVs}$ choice of best fit is made based on flat values and for remaining five $\mathrm{CVs}$, it is based on values of least reduced chi-square and best extendability produced at node numbers 80,100 and 120 .

iv. The subsequent parameter values for each R_CBR_Dist CV equation are noted.

\subsection{Trend Analysis - R CBR Dist CV1.}

The plots depict two distinct ranges as follows:

$$
F(x)=\left\{\begin{array}{lr}
0 & 7 \leq x \leq 9 \\
1 & x \geq 10
\end{array}\right.
$$

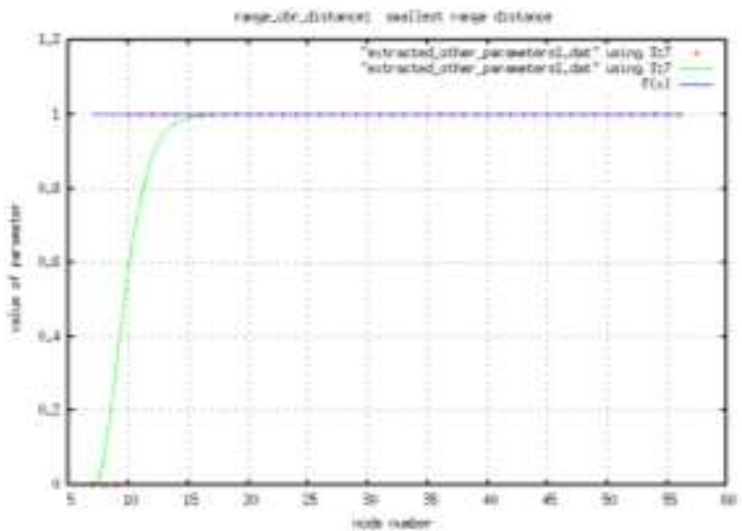

Figure 1: R_CBR_Dist Critical Value 1

\subsection{Trend Analysis - R_CBR_Dist CV2.}

Four series of observations are made here as follows:

\begin{tabular}{|c|c|}
\hline Node & Y-axis \\
\hline $7-9$ & 0.555 \\
\hline $10-12$ & 0.238 \\
\hline $13-16$ & 0.159 \\
\hline $17-$ & 0.079 \\
\hline
\end{tabular}

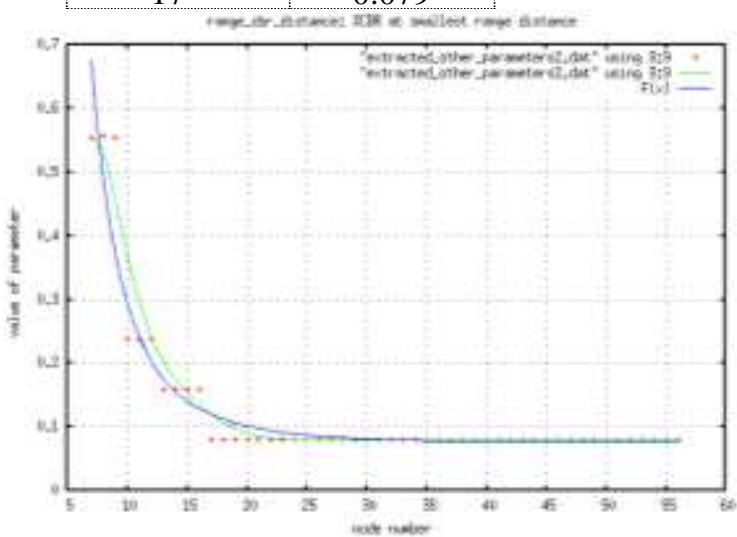

Figure 2: R_CBR_Dist Critical Value 2

For node number 17 and above, the projected value can safely be assumed at 0.079 .
The potentially applicable equations are:

$$
\begin{aligned}
& \text { 1. } F(x)=\left(\left(a * x^{-1}\right) / \log (x)\right)+b \\
& \text { Ch_sq }=0.00213996 \\
& \text { 2. } F(x)=\left(\left(\left(a * x^{-1}\right)+b\right) / \log (x+c)\right)+d \\
& \text { Ch_sq }=0.00111038 \quad \mathrm{~F}(80)=0.122230167 \\
& \mathrm{~F}(100)=0.142421090 \quad \mathrm{~F}(120)=0.159337046 \\
& \text { 3. } F(x)=\left(\left(\left(a^{*} x^{-2}\right)+b\right) / \log (x+c)+d\right. \\
& \text { Ch_sq }=0.00116949 \quad \mathrm{~F}(80)=0.126519388 \\
& \mathrm{~F}(100)=0.157740250 \quad \mathrm{~F}(120)=0.188924115 \\
& \text { 4. } F(x)=\left(\left(\left(a^{*} x^{-2.8}\right)+b\right) / \log (x+c)+d\right. \\
& \text { Ch_sq }=0.00141684 \quad \mathrm{~F}(80)=0.079943120 \\
& F(100)=0.082866289 \quad F(120)=0.085878074
\end{aligned}
$$

Choice of best fit for R_CBR_Dist Critical Value 2 The equation in part 4 above has been selected because of best extendability even if ch_sq is not least. The parameters for best fit are:

$a=974.855, b=-8.27327, c=966.745, d=1.26909$

\subsection{Trend Analysis - R_CBR_Dist CV3.}

Instead of a consistent curve of tendency, 4 distinct levels of largest range distance are noted.

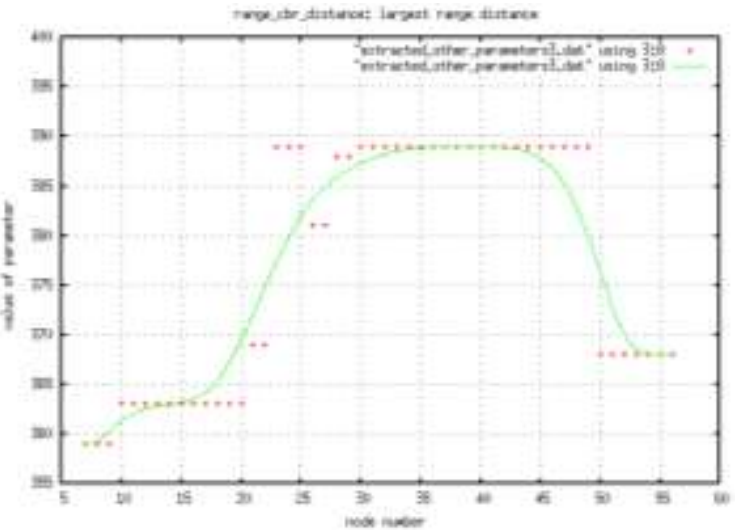

Figure 3: R_CBR_Dist Critical Value 3

\begin{tabular}{|l|l|l|}
\hline Level Number & Node Numbers & Y-axis Value \\
\hline 1 & $7-9$ & 359 \\
\hline 2 & $10-22$ & 363 \\
\hline 3 & $23-49$ & 389 \\
\hline 4 & $50-56$ & 368 \\
\hline
\end{tabular}

Range of Node_numbers for level 1 until 3 depict an increasing value. It can be suggested that level 4 will hold for node numbers around 50 - 90 .

The observations resemble those of PPD CV3 [58], but are not identical.

\subsection{Trend Analysis - R_CBR_Dist CV4.}

Here, mostly 3 distinct levels are noted in the plots. A few exceptions to these levels is acknowledged.

\begin{tabular}{|l|l|}
\hline Node Numbers & Y-axis Value \\
\hline $7-9$ & 0.079 \\
\hline $10-20$ & 0.317 \\
\hline $21-$ & 0.238 \\
\hline
\end{tabular}


Proc. of The Seventh Intl. Conf. On Advances In Computing, Control And Networking - ACCN 2017 Copyright $(\subseteq$ Institute of Research Engineers and Doctors, USA .All rights reserved. ISBN: 978-1-63248-134-4 doi: 10.15224/ 978-1-63248-134-4-08

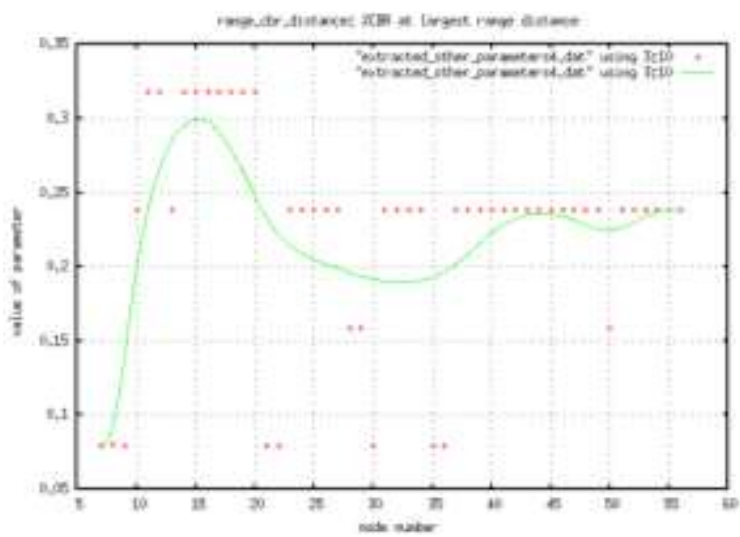

Figure 4: R_CBR_Dist Critical Value 4

\subsection{Trend Analysis $-R \quad C B R$ Dist CV5.}

Mostly a mildly increasing linear tendency is observed.

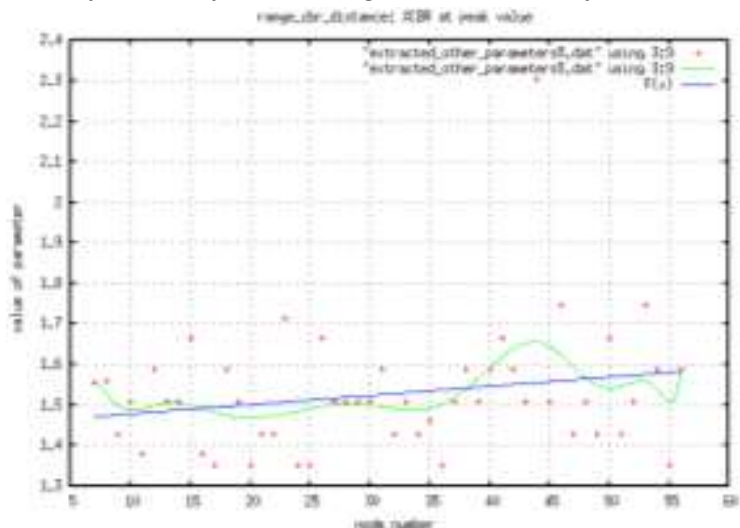

Figure 5: R_CBR_Dist Critical Value 5

The applicable equation is: $F(x)=d^{*} x+f$

$$
\begin{array}{ll}
\text { Ch_sq }=0.0230967 & \mathrm{~F}(80)=1.637285588 \\
\mathrm{~F}(100)=1.682699120 & \mathrm{~F}(120)=1.728112652
\end{array}
$$

Parameters for best fit: $\mathrm{d}=0.00227068, \mathrm{f}=1.45563$

A tolerance of \pm 0.2 is also suggested.

\subsection{Trend Analysis $-R \_C B R \_D i s t C V 6$.}

The plots are very scattered. Mostly a very mildly increasing linear tendency is observed.

The applicable equation is: $F(x)=d^{*} x+f$

$$
\begin{array}{ll}
\text { Ch_sq }=199.322 & F(80)=59.425895617 \\
F(100)=61.180254691 & F(120)=62.934613764
\end{array}
$$

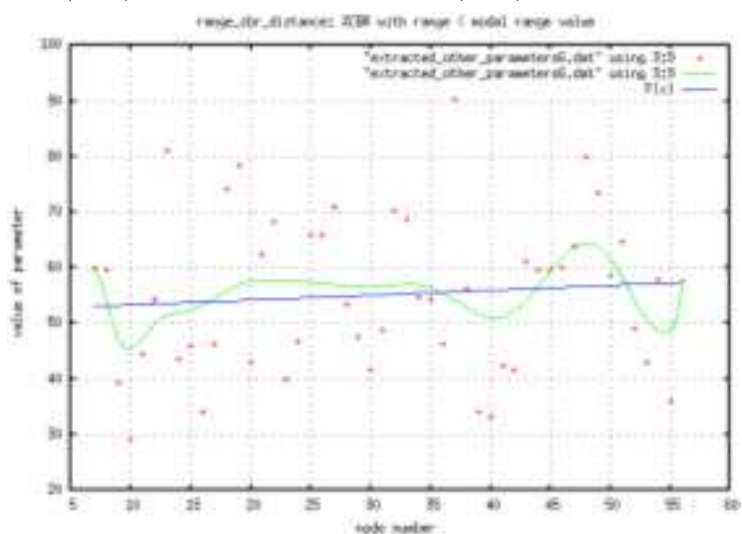

Figure 6: R_CBR_Dist Critical Value 6

Parameters for best fit are: $\mathrm{d}=0.087718, \mathrm{f}=52.4085$
A tolerance of \pm 15 is also suggested.

\subsection{Trend Analysis - R CBR Dist CV7.}

Here also the plots are very scattered. Mostly a very mildly decreasing linear tendency is observed. A tolerance of \pm 15 is also suggested.

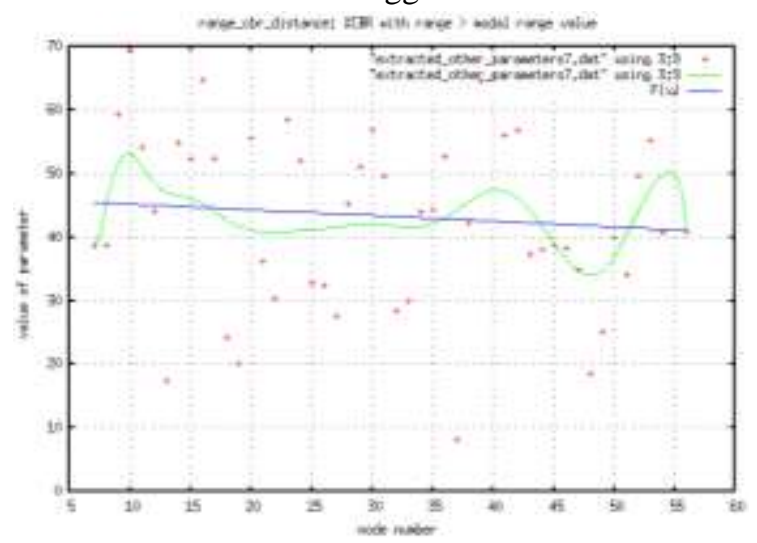

Figure 7: R_CBR_Dist Critical Value 7

The applicable equation is: $F(x)=d^{*} x+f$

$$
\begin{array}{ll}
\text { Ch_sq }=199.41 & F(80)=38.936818793 \\
F(100)=37.137046188 & F(120)=35.337273582
\end{array}
$$

Parameters for best fit are: $d=-0.0899886, f=46.1359$

\subsection{Trend Analysis $-R \_C B R \_$Dist CV8.}

The plots obtained here depict an increasing tendency at a decreasing rate. Some staircase features due to rounding off distance values are also noted.

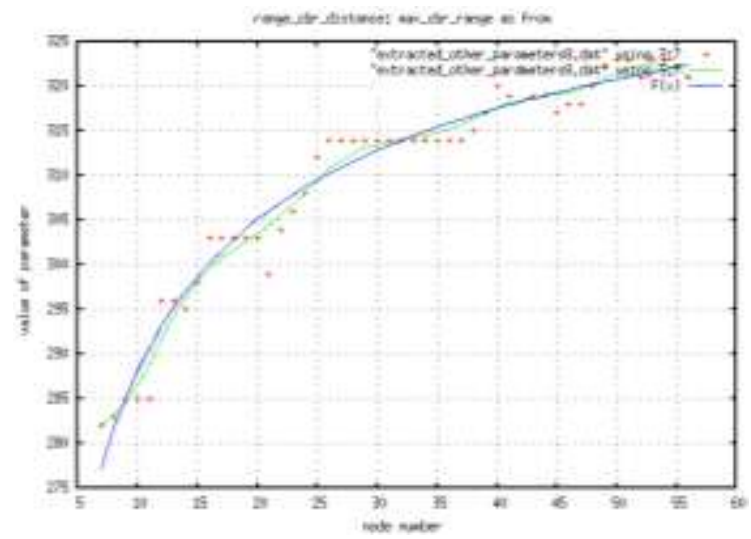

Figure 8: R_CBR_Dist Critical Value 8

The potentially applicable equations are:

$$
\begin{aligned}
& \text { 1. } F(x)=a * \log ((b * x)+c)+d \\
& \text { Ch_sq }=5.87003 \quad \mathrm{~F}(80)=329.910734899 \\
& F(100)=333.799355886 \quad F(120)=336.953832213 \\
& \text { 2. } F(x)=a * \log ((b * x)+c)+(d * x) \\
& \text { Ch_sq }=5.32438 \quad \mathrm{~F}(80)=324.132113899 \\
& \mathrm{~F}(100)=323.358918897 \quad \mathrm{~F}(120)=321.282940355 \\
& 3 \cdot F(x)=a * \log ((b * x)+c)+(d / x) \\
& \text { Ch_sq }=5.77122 \quad \mathrm{~F}(80)=329.838981295 \\
& F(100)=333.672024386 \quad F(120)=336.771464703 \\
& \text { 4. } F(x)=a \star x^{-1} \star \log ((b * x)+c)+d \\
& \text { Ch_sq }=10.5633 \quad \mathrm{~F}(80)=322.228357523 \\
& \mathrm{~F}(100)=323.285278074 \quad \mathrm{~F}(120)=323.997260041 \\
& \text { 5. } F(x)=a * x^{-0.5} * \log ((b * x)+c)+d \\
& \text { Ch_sq }=5.76318 \quad \mathrm{~F}(80)=326.747839244 \\
& F(100)=329.148274666 \quad F(120)=330.939664370
\end{aligned}
$$




$$
\begin{array}{rl}
\text { 6. } F(x)=a * x^{-0.25} \star \log & ((b * x)+c)+d \\
\text { Ch_sq }=5.71252 & F(80)=329.535900100 \\
F(100)=333.047201745 & F(120)=335.807762148 \\
\text { 7. } \mathrm{F}(\mathrm{x})=\mathrm{a} \star \mathrm{x}^{-0.75} \star & \log ((\mathrm{b} * \mathrm{x})+\mathrm{C})+\mathrm{d} \\
\text { Ch_sq }=7.42198 & \mathrm{~F}(80)=324.328018252 \\
\mathrm{~F}(100)=325.939514600 & \mathrm{~F}(120)=327.082046714
\end{array}
$$

\section{Choice of best fit for R_CBR_Dist Critical Value 8}

The equation in part 5 above has been selected because of best extendability even if ch_sq is not least. The parameters obtained for best fit are:

$a=-10.9806, b=9.14866\left(e^{+06}\right), c=1883.39, d=351.806$

\section{Conclusion.}

This empirical study was intended to identify the relevant CVs observable for metric R_CBR_Dist and analyse their corresponding trends over varying node densities in a MANET topography of $300 \times 300 \mathrm{~m}^{2}$. The models depicted in this paper, are composed of quite complex mathematical equations. The output displayed here will fortify the existing tools for better studies of MANETs for ubicomp environments as viewed by software engineers. These results may be suitably implemented into computational methods to generate better simulation scenarios which will subsequently serve for allowing more refined testing over communication and middleware components.

This experiment was executed in NS-2 over Linux. Attempts for plottings and "fit" were done with gnuplot. Designation of best fit was based on values of least reduced chi-square and best extendability observed at higher node numbers for five CVs and on flat values for three CVs. The assumptions mentioned in previous paper $[29,45]$ are maintained here also.

This investigation stands as a follow-up of previous ones [1-60]. The results presented here remain open for future upgrades. One such possible work identified remains the formulation of predictability for metric R_CBR_Dist and its trend.

\section{References}

[1] M. Kaleem GALAMALI, Assoc. Prof Nawaz MOHAMUDALLY, Towards Dependable Pervasive Systems-A Position and Vision Paper, CEET 2014

[2] M. Kaleem GALAMALI, Assoc. Prof Nawaz MOHAMUDALLY, Model of Energy Savings achievable with Location-aware Node-to-Node Transmission in UbiComp , CEET 2014

[3] M. Kaleem GALAMALI, Assoc. Prof Nawaz MOHAMUDALLY, Model of Energy Savings achievable with Location-aware Node-to-Node Transmission in UbiComp Using Location Refresh Intervals, CEET 2014

[4] M. Kaleem GALAMALI, Assoc. Prof Nawaz MOHAMUDALLY, Model of Energy Savings achievable with Location-aware Transmission in UbiComp Using Relays, CEET 2014

[5] M. Kaleem GALAMALI, Assoc. Prof Nawaz MOHAMUDALLY, Mathematical modeling of need of exact number of relays to ensure seamless mobility in mobile computing, CEET 2014

[6] M. Kaleem GALAMALI, Assoc. Prof Nawaz MOHAMUDALLY, Modelling of need for multiple relays for ensuring seamless mobility, CEET 2014

[7] M. Kaleem GALAMALI, Assoc. Prof Nawaz MOHAMUDALLY, Investigation of prominence of placements of relays in a ubicomp topography,

[8] M. Kaleem GALAMALI, Assoc. Prof Nawaz MOHAMUDALLY, Model of energy savings achievable with location-aware transmission in ubicomp using optimised number of relays.

[9] M. Kaleem GALAMALI, Assoc. Prof Nawaz MOHAMUDALLY, Investigation of Prominence of Placements of Optimised Number of Relays in a Ubicomp Topography using Location-Aware Transmission, CEET 2015.

[10] M. Kaleem GALAMALI, Assoc. Prof Nawaz MOHAMUDALLY, Extending Node Battery Availability in Ubicomp with Location-Aware Transmission, CEET 2015.

[11] M. Kaleem GALAMALI, Assoc. Prof Nawaz MOHAMUDALLY, Extending Node Battery Availability in Ubicomp with Location-Aware Transmission using Location Refresh Intervals, CEET 2015.

[12] M. Kaleem GALAMALI, Assoc. Prof Nawaz MOHAMUDALLY, Extending Node Battery Availability in Ubicomp with Location-Aware Transmission using Uniformly Placed Relays, CEET 2015

[13] M. Kaleem GALAMALI, Assoc. Prof Nawaz MOHAMUDALLY, Extending Node Battery Availability in Ubicomp with Location-Aware Transmission Using Optimally Placed Relays, CEET 2015.

[14] M. Kaleem GALAMALI, Assoc. Prof Nawaz MOHAMUDALLY, Model of Sender Node Energy Savings Achievable with Location-Aware MANET Transmission in Ubicomp. ACCN 2016

[15] M. Kaleem GALAMALI, Assoc. Prof Nawaz MOHAMUDALLY, Model of Overall Node Energy Savings Achievable with Location-Aware MANET Transmission in Ubicomp. ACCN 2016

[16] M. Kaleem GALAMALI, Assoc. Prof Nawaz MOHAMUDALLY, Model of Sender Node Extra Energy Savings Achievable in MANET Against Direct Node-to-Node Transmission Using Location-Aware Transmission in Ubicomp. ACCN 2016

[17] M. Kaleem GALAMALI, Assoc. Prof Nawaz MOHAMUDALLY, Model of Overall Node Extra Energy Savings Achievable in MANET against Direct Node-to-Node Transmission Using Location-Aware Transmission in Ubicomp. ACCN 2016

[18] M. Kaleem GALAMALI, Assoc. Prof Nawaz MOHAMUDALLY, Model of Energy Consumption Ratio Achievable in MANET Using Location-Aware Transmission in Ubicomp. ACCN 2016

[19] M. Kaleem GALAMALI, Assoc. Prof Nawaz MOHAMUDALLY, Model of Minimum Energy Consumption Ratio Achievable in MANET Using LocationAware Transmission in Ubicomp. ACCN 2016

[20] M. Kaleem GALAMALI, Assoc. Prof Nawaz MOHAMUDALLY, Model of Maximum Energy Consumption Ratio Achievable in MANET Using LocationAware Transmission in Ubicomp. ACCN 2016

[21] M. Kaleem GALAMALI, Assoc. Prof Nawaz MOHAMUDALLY, Model of Overall Energy Consumption Fairness Ratio Achievable in MANET Using Location-Aware Transmission in Ubicomp. ACCN 2016

[22] M. Kaleem GALAMALI, Assoc. Prof Nawaz MOHAMUDALLY, Model of Overall Energy Consumption Fairness Proportion Achievable in MANET Using LocationAware Transmission for Ubicomp, CEET 2016

[23] M. Kaleem GALAMALI, Assoc. Prof Nawaz MOHAMUDALLY, Model of Minimum Fairness Proportion Achievable in MANET Using Location-Aware Transmission for Ubicomp, CEET 2016

[24] M. Kaleem GALAMALI, Assoc. Prof Nawaz 
MOHAMUDALLY, Model of Maximum Fairness Proportion Achievable in MANET Using Location-Aware Transmission for Ubicomp, CEET 2016

[25] M. Kaleem GALAMALI, Assoc. Prof Nawaz MOHAMUDALLY, Model of Sender Fairness Proportion Achievable in MANET Using Location-Aware Transmission for Ubicomp, CEET 2016

[26] M. Kaleem GALAMALI, Assoc. Prof Nawaz MOHAMUDALLY, Model of Distance Travelled by packets in MANETs using Location-Aware Transmission for Ubicomp, CEET 2016

[27] M. Kaleem GALAMALI, Assoc. Prof Nawaz MOHAMUDALLY, Model of Maximum CBR Distance Travelled by packets in MANETs using Location-Aware Transmission for Ubicomp, CEET 2016

[28] M. Kaleem GALAMALI, Assoc. Prof Nawaz MOHAMUDALLY, Model of Minimum CBR Distance Travelled by packets in MANETs using Location-Aware Transmission for Ubicomp, CEET 2016

[29] M. Kaleem GALAMALI, Assoc. Prof Nawaz MOHAMUDALLY, Model of Range CBR Distance Experienced by Transmissions in MANETs using LocationAware Transmission for Ubicomp, CEET 2016

[30] M. Kaleem GALAMALI, Assoc. Prof Nawaz MOHAMUDALLY, Trend Analyses of Parameters of Equations for Sender Node Energy Savings Achievable in ubicomp MANETs using Location-Aware Transmission, ACCN 2017.

[31] M. Kaleem GALAMALI, Assoc. Prof Nawaz MOHAMUDALLY, Trend Analyses of Parameters of Equations for Overall Node Energy Savings Achievable in ubicomp MANETs using Location-Aware Transmission, ACCN 2017.

[32] M. Kaleem GALAMALI, Assoc. Prof Nawaz MOHAMUDALLY, Trend Analyses of Parameters of Equations for Sender Node Extra Energy Savings Achievable in MANET against Direct Node-to-Node Location-Aware Transmission, ACCN 2017.

[33] M. Kaleem GALAMALI, Assoc. Prof Nawaz MOHAMUDALLY, Trend Analyses of Parameters of Equations for Overall Nodes Extra Energy Savings Achievable in MANET against Direct Node-to-Node Location-Aware Transmission, ACCN 2017.

[34] M. Kaleem GALAMALI, Assoc. Prof Nawaz MOHAMUDALLY, Trend Analyses of Parameters of Equations for Energy Consumption Ratio Achievable in Ubicomp MANET Using Location-Aware Transmission, ACCN 2017.

[35] M. Kaleem GALAMALI, Assoc. Prof Nawaz MOHAMUDALLY, Trend Analyses of Parameters of Equations for Minimum Energy Consumption Ratio Achievable in Ubicomp MANETs Using Location-Aware Transmission, ACCN 2017.

[36] M. Kaleem GALAMALI, Assoc. Prof Nawaz MOHAMUDALLY, Trend Analyses of Parameters of Equations for Maximum Energy Consumption Ratio Achievable in Ubicomp MANETs Using Location-Aware Transmission, ACCN 2017.

[37] M. Kaleem GALAMALI, Assoc. Prof Nawaz MOHAMUDALLY, Trend Analyses of Parameters of Equations for Overall Fairness Ratio Achievable in Ubicomp MANETs Using Location-Aware Transmission, ACCN 2017.

[38] M. Kaleem GALAMALI, Assoc. Prof Nawaz MOHAMUDALLY, Trend Analyses of Parameters of Equations for Energy Consumption Fairness Proportion Achievable in Ubicomp MANETs Using Location-Aware Transmission, CEET 2017

[39] M. Kaleem GALAMALI, Assoc. Prof Nawaz MOHAMUDALLY, Trend Analyses of Parameters of Equations for Minimum Fairness Proportion Achievable in Ubicomp MANETs Using Location-Aware Transmission, CEET 2017

[40] M. Kaleem GALAMALI, Assoc. Prof Nawaz MOHAMUDALLY, Trend Analyses of Parameters of Equations for Maximum Fairness Proportion Achievable in Ubicomp MANETs Using Location-Aware Transmission, CEET 2017

[41] M. Kaleem GALAMALI, Assoc. Prof Nawaz MOHAMUDALLY, Trend Analyses of Parameters of Equations for Sender Fairness Proportion Achievable in Ubicomp MANETs Using Location-Aware Transmission, CEET 2017
[42] M. Kaleem GALAMALI, Assoc. Prof Nawaz MOHAMUDALLY, Trend Analyses of Parameters of Equations for Packets Per Distance Achievable in Ubicomp MANETs Using Location-Aware Transmission, CEET 2017

[43] M. Kaleem GALAMALI, Assoc. Prof Nawaz MOHAMUDALLY, Trend Analyses of Parameters of Equations for Maximum CBR Distance Achievable in Ubicomp MANETs Using Location-Aware Transmission, CEET 2017

[44] M. Kaleem GALAMALI, Assoc. Prof Nawaz MOHAMUDALLY, Trend Analyses of Parameters of Equations for Minimum CBR Distance Achievable in Ubicomp MANETs Using Location-Aware Transmission, CEET 2017

[45] M. Kaleem GALAMALI, Assoc. Prof Nawaz MOHAMUDALLY, Trend Analyses of Parameters of Equations for Range CBR Distance Achievable in Ubicomp MANETs Using Location-Aware Transmission, CEET 2017

[46] M. Kaleem GALAMALI, Assoc. Prof Nawaz MOHAMUDALLY, Trend Analyses of Critical Values Obtained for Sender Node Energy Savings Achievable in Ubicomp MANETs Using Location-Aware Transmission, CEET 2017

[47] M. Kaleem GALAMALI, Assoc. Prof Nawaz MOHAMUDALLY, Trend Analyses of Critical Values Obtained for Overall Node Energy Savings Achievable in Ubicomp MANETs Using Location-Aware Transmission, CEET 2017

[48] M. Kaleem GALAMALI, Assoc. Prof Nawaz MOHAMUDALLY, Trend Analyses of Critical Values Obtained for Sender Node Extra Energy Savings Achievable in Ubicomp MANET Against Direct Node-to-Node LocationAware Transmission, CEET 2017

[49] M. Kaleem GALAMALI, Assoc. Prof Nawaz MOHAMUDALLY, Trend Analyses of Critical Values Obtained for Overall Nodes Extra Energy Savings Achievable in Ubicomp MANET Against Direct Node-to-Node LocationAware Transmission, CEET 2017

[50] M. Kaleem GALAMALI, Assoc. Prof Nawaz MOHAMUDALLY, Trend Analyses of Critical Values Obtained for Energy Consumption Ratio Achievable in Ubicomp MANETs Using Location-Aware Transmission Strategies, CEET 2017

[51] M. Kaleem GALAMALI, Assoc. Prof Nawaz MOHAMUDALLY, Trend Analyses of Critical Values Obtained for Minimum Energy Consumption Ratio Achievable in Ubicomp MANETs Using Location-Aware Transmission Strategies, CEET 2017

[52] M. Kaleem GALAMALI, Assoc. Prof Nawaz MOHAMUDALLY, Trend Analyses of Critical Values Obtained for Maximum Energy Consumption Ratio Achievable in Ubicomp MANETs Using Location-Aware Transmission Strategies, CEET 2017

[53] M. Kaleem GALAMALI, Assoc. Prof Nawaz MOHAMUDALLY, Trend Analyses of Critical Values Obtained for Overall Fairness Ratio Achievable in Ubicomp MANETs Using Location-Aware Transmission Strategies, CEET 2017

[54] M. Kaleem GALAMALI, Assoc. Prof Nawaz MOHAMUDALLY, Trend Analyses of Critical Values Obtained for Energy Consumption Fairness Proportion Achievable in Ubicomp MANETs Using Location-Aware Transmission Strategies, ACCN 2017.

[55] M. Kaleem GALAMALI, Assoc. Prof Nawaz MOHAMUDALLY, Trend Analyses of Critical Values Obtained for Minimum Fairness Proportion Achievable in Ubicomp MANETs Using Location-Aware Transmission Strategies, ACCN 2017.

[56] M. Kaleem GALAMALI, Assoc. Prof Nawaz MOHAMUDALLY, Trend Analyses of Critical Values Obtained for Maximum Fairness Proportion Achievable in Ubicomp MANETs Using Location-Aware Transmission Strategies, ACCN 2017.

[57] M. Kaleem GALAMALI, Assoc. Prof Nawaz MOHAMUDALLY, Trend Analyses of Critical Values Obtained for Sender Fairness Proportion Achievable in Ubicomp MANETs Using Location-Aware Transmission Strategies, ACCN 2017.

[58] M. Kaleem GALAMALI, Assoc. Prof Nawaz MOHAMUDALLY, Trend Analyses of Critical Values Obtained for Packets Per Distance Achievable in Ubicomp MANETs Using Location-Aware Transmission Strategies, ACCN 2017. 
[59] M. Kaleem GALAMALI, Assoc. Prof Nawaz MOHAMUDALLY, Trend Analyses of Critical Values Obtained for Maximum CBR Distance Achievable in Ubicomp MANETs Using Location-Aware Transmission Strategies, ACCN 2017.

[60] M. Kaleem GALAMALI, Assoc. Prof Nawaz MOHAMUDALLY, Trend Analyses of Critical Values Obtained for Minimum CBR Distance Achievable in Ubicomp MANETs Using Location-Aware Transmission Strategies, ACCN 2017.

[61] Markus Bylund and Zary Segall, Towards seamless mobility with personal servers, 2004

[62] Masugi Inoue, Mikio Hasegawa, Nobuo Ryoki and Hiroyuki Morikawa, Context-Based Seamless Network and Application Control, 2004

[63] Xiang Song, Umakishore Ramachandran, MobiGo: A Middleware for Seamless Mobility, College of Computing Georgia Institute of Technology, Atlanta, GA, USA, August 2007

[64] Budzisz, Ferrús, R., Brunstrom A., Grinnemo, K, Fracchia, R., Galante, G., and Casadevall, F. Towards transport-layer mobility: Evolution of SCTP multihoming, March 2008

[65] Paul Dourish \& Genevieve Bell, Divining a digital future, 2011

[66] Xiang Song, Seamless Mobility In Ubiquitous Computing Environments, $\mathrm{PhD}$ Thesis, Georgia Institute of Technology, August 2008

[67] Kevin O Mahony, Jian Liang, Kieran Delaney, User-Centric Personalization and Autonomous Reconfiguration Across Ubiquitous Computing Environments, NIMBUS Centre Cork Institute of Technology, Cork, Ireland, UBICOMM 2012

[68] Pablo Vidales, Seamless mobility in $4 \mathrm{G}$ systems, Technical Report, University of Cambridge, Computer Laboratory, Number 656, November 2005

[69] João Pedro Sousa and David Garlan, Aura: An Architectural Framework for User Mobility in Ubiquitous Computing Environments, School of Computer Science, Carnegie Mellon University, USA, August 2002

[70] Dennis Lupiana, Ciaran O'Driscoll, Fredrick Mtenzi, Defining Smart Space in the Context of Ubiquitous Computing, Dublin Institute of Technology, Ireland, Special Issue on ICIT 2009 Conference - Web and Agent Systems, 2009

[71] N.S.V.Shet1, Prof.K.Chandrasekaran2 and Prof. K.C.Shet3, WAP Based Seamless Roaming In Urban Environment with Wise Handoff Technique, International Journal of UbiComp (IJU), Vol.1, No.4, October 2010

[72] Yipeng Yu Dan He Weidong Hua Shijian Li Yu Qi Yueming Wang Gang Pan, FlyingBuddy2: A Brain-controlled Assistant for the Handicapped, Zhejiang University, UbiComp'12, September 5-8, 2012.

[73] Jing Su, James Scott, Pan Hui, Jon Crowcroft, Eyal de Lara Christophe Diot, Ashvin Goel, Meng How Lim, and Eben Upton, Haggle: Seamless Networking for Mobile Applications, 2007

[74] Rui Han, Moustafa M. Ghanem, Li Guo, Yike Guo*, Michelle Osmond, Enabling cost-aware and adaptive elasticity of multi-tier cloud applications, Future Generation Computer Systems, 2012

[75] Byrav Ramamurthy, K. K. Ramakrishnan, Rakesh K. Sinha, Cost and Reliability Considerations in Designing the NextGeneration IP over WDM Backbone Networks, 2012

[76] Bhavish Aggarwal, Aditya Akella, Ashok Anand, Athula Balachandran, Pushkar Chitnis, Chitra Muthukrishnan, Ram Ramjee and George Varghese, EndRE: An End-System Redundancy Elimination Service for Enterprises, NSDI 2010, San Jose, CA

[77] Ashok Anand, Vyas Sekar and Aditya Akella, SmartRE: An Architecture for Coordinated Network-wide Redundancy Elimination, SIGCOMM 2009, Barcelona, Spain

[78] John Breeden II, "Smart-phone battery life could double without better batteries", Nov 14, 2012

[79] Andy Boxall, "When will your phone battery last as long as your kindle", December 5, 2012

[80] Imielinski, T. and Navas, J.C. (1999). GPS-based geographic addressing, routing, and resource discovery. Comms. ACM, Vol. 42, No. 4, pp. 86-92.

[81] Hightower, J. and Borriello, G. (2001). Location Systems for Ubiquitous Computing. IEEE Computer, Vol. 34, No. 8, August, pp. 57-66.

[82] Harter, A., Hopper, A., Steggles, P., Ward, A. and Webster, P. (2002). The Anatomy of a Context-Aware Application. Wireless Networks, Vol. 8, No. 2-3, Mar-May, pp. 187-197.

[83] Hightower, J., Brumitt, B. and Borriello, G. (2002). The
Location Stack: A Layered Model for Location in Ubiquitous Computing. Proceedings of the 4th IEEE Workshop on Mobile Computing Systems \& Applications (WMCSA 2002), Callicoon, NY, USA, June, pp. 22-28.

[84] Graumann, D., Lara, W., Hightower, J. and Borriello, G. (2003) Real-world implementation of the Location Stack: The Universal Location Framework. Proceedings of the 5th IEEE Workshop on Mobile Computing Systems \& Applications (WMCSA 2003), Monterey, CA, USA, October, pp. 122-128.

[85] Ko, Y., \& Vaidya, N. H. (2000). Location-aided routing (LAR) in mobile ad hoc networks. Wireless Networks, 6(4), 307-321.

[86] Liao, W.-H., Tseng, Y.-C., \& Sheu, J.-P. (2001). GRID: a fully location-aware routing protocol for mobile ad hoc networks. Telecommunication Systems, 18(1), 37-60.

[87] Kuhn, F., Wattenhofer, R., Zhang, Y., \& Zollinger, A. (2003). Geometric ad-hoc routing: of theory and practice. In Proceedings of the ACM (PODC'03) (pp. 63-72).

[88] Jiang, X., \& Camp, T. (2002). Review of geocasting protocols for a mobile ad hoc network. In Proceedings of the Grace Hopper Celebration (GHC).

[89] Ko, Y. \& Vaidya, N. H. (1999). Geocasting in mobile ad hoc networks: location-based multicast algorithms. In Proceedings of the IEEE (WMCSA'99) (pp. 101).

[90] Mauve, M., Fuler, H., Widmer, J., \& Lang, T. (2003). Position-based multicast routing for mobile ad-hoc networks (Technical Report TR-03-004). Department of Computer Science, University of Mannheim.

[91] Xu, Y., Heidemann, J., \& Estrin, D. (2001). Geographyinformed energy conservation for adhoc routing. In Proceedings of the ACM/IEEE (MOBICOM'01) (pp. 70-84).

[92] Hu, Y.-C., Perrig, A., \& Johnson, D. (2003). Packet leashes: a defense against wormhole attacks in wireless ad hoc networks. In Proceedings of the INFOCOM' 03 (pp. 1976-1986).

[93] Patwari, N., Hero III, A. O., Perkins, M., Correal, N. S., \& O'Dea, R. J. (2003). Relative location estimation in wireless sensor networks. IEEE Transactions on Signal Processing, 51(8), 2137-2148.

[94] Baldauf, M., Dustdar, S., \& Rosenberg, F. (2007). A Survey on Context Aware Systems. International Journal of Ad Hoc and Ubiquitous Computing, Inderscience Publishers. forthcoming. Pre-print from: http://www.vitalab.tuwien.ac.at/ florian/papers/ijahuc2007.pdf

[95] Hong, D., Chiu, D.K.W., \& Shen, V.Y. (2005). Requirements elicitation for the design of context-aware applications in a ubiquitous environment. In Proceedings of ICEC'05 (pp. 590596).

[96] Neeraj Tantubay, Dinesh Ratan Gautam and Mukesh Kumar Dhariwal, A Review of Power Conservation in Wireless Mobile Ad hoc Network (MANET)", International Journal of computer Science Issues, Vol 8, Issue 4, No 1, July 2011.

[97] Wenrui Zhao, Mostafa Ammar and Ellen Zegura, "A Message Ferrying Approach for Data Delivery in Sparse Mobile Ad Hoc Networks", MobiHoc'04, May 24-26, 2004, Roppongi, Japan.

[98] Sgroi et al., "Designing Wireless Protocols: Methodology and Applications, February 2000

[99] Gyula et al., "Simulation-based optimization of communication protocols for large-scale wireless sensor networks", 10 October 2002

[100] Rao and Sharma, "Cross Layer Protocols For Multimedia Transmission in Wireless Networks", June 2012

[101] Herms et al, "Realism in Design and Evaluation of Wireless Routing Protocols", 2007.

About Author (s):

Associate Professor Nawaz Mohamudally works at University of Technology, Mauritius (UTM) and has undertaken supervision of MPhil/PhD Students for many years. 
Proc. of The Seventh Intl. Conf. On Advances In Computing, Control And Networking - ACCN 2017 Copyright $(\subseteq$ Institute of Research Engineers and Doctors, USA .All rights reserved.

ISBN: 978-1-63248-134-4 doi: 10.15224/ 978-1-63248-134-4-08

M. Kaleem Galamali is a part-time student (achieved M Phil Transfer on 28.10.2014, currently PhD student) at UTM under supervision of A.P. Nawaz Mohamudally. 